\title{
OS PADRÕES DE DEMOCRACIA INTRAPARTIDÁRIA NA AMÉRICA DO SUL: UMA ABORDAGEM COMPARATIVA
}

Ricardo Silveira Castro ${ }^{1}$

\section{Resumo}

O presente estudo parte de uma abordagem comparativa entre os marcos regulatórios dos processos de tomada de decisão intrapartidária nos países sul-americanos (Argentina, Brasil, Bolívia, Chile, Colômbia, Equador, Paraguai, Peru, Uruguai e Venezuela) para analisar a potencialidade e as limitações dos padrões existentes. Mesmo havendo resquícios do modelo institucional do constitucionalismo de fusão como entraves ao aprofundamento democrático no século XXI, reconhecemos ser possível superá-los a partir de uma reformulação na teoria política contemporânea.

Palavras-chave: Democracia; partidos políticos; América do Sul; sistema político;

\section{INTRA-PARTY DEMOCRACY: A COMPARATIVE APPROACH BETWEEN SOUTH AMERICAN STANDARDS}

\begin{abstract}
This study is based on a comparative approach between the regulatory frameworks of intraparty decision-making processes in South American countries (Argentina, Brazil, Bolivia, Chile, Colombia, Ecuador, Paraguay, Peru, Uruguay and Venezuela) to analyze the potential and limitations of existing standards. Even though there are remnants of the institutional model of fusion constitutionalism as obstacles to democratic deepening in the 21st century, we recognize that it is possible to overcome them through a reformulation in contemporary political theory.
\end{abstract}

Keywords: Democracy; political parties; South America; political system;

\section{Introdução:}

De uma maneira geral, as democracias que emergem dos processos de transição política ocorridos na América Latina a partir da década de 1980 têm como base institucional basilar a redefinição da matriz regulatória das organizações partidárias. É justamente com base no enfoque dessas normas (constitucional e infraconstitucional) que o presente estudo identifica os padrões de regulamentação dos processos de tomada de decisão intrapartidários, com o fim de

\footnotetext{
${ }^{1}$ Advogado. Doutorando e Mestre em Direito pela Universidade Federal do Rio Grande do Sul. Professor do Curso de Direito das Faculdades Integradas de Taquara (FACCAT). Integrante do Grupo de Pesquisa "Constitucionalismo na América Latina”. E-mail: silveiraricardocastro@gmail.com.
} 
analisar os traços de continuidade do projeto constitucional liberal-conservador na institucionalidade democrática vigente na contemporaneidade.

É lugar comum nos trabalhos acadêmicos recentes da Ciência Política e do Direito o fato de que as democracias contemporâneas têm como suporte central o funcionamento organizado das entidades partidárias (ZOVATTO, 2006), ainda que muito esteja sendo discutido a respeito da crise de legitimidade desses atores fundamentais nos sistemas políticos vigentes (KATZ e MAIR, 1994). A questão envolvendo a democracia interna aos partidos políticos, entretanto, é objeto de debates mais acentuado entre posturas políticas consideravelmente polarizadas.

Sinteticamente, podemos compreender a ideia de democracia intrapartidária como a aplicação do conjunto de princípios do sistema democrático no interior da associação partidária. Nesse sentido, o grau de democracia intrapartidária estaria relacionado mais especificamente com a existência de regras que incluam a viabilidade da competição dentro do partido, com o reconhecimento da participação política dos cidadãos nos processos de tomada de decisão política institucionalizados pelas entidades partidárias (FREIDENBERG, 2006).

É evidente que premissas teóricas diferentes a respeito do conteúdo do regime institucional democrático repercutirão diretamente na compreensão da conveniência política (ou não) da adoção de regras de democracia intrapartidária em um determinado sistema político. No presente estudo, entretanto, adotaremos o referencial teórico segundo o qual os partidos políticos deveriam institucionalizar uma democracia interna baseada na teoria da democracia deliberativa (TEORELL, 1999; NINO, 2011).

Consequentemente, a adoção do referencial teórico da democracia deliberativa tem reflexo metodológico imediato na análise dos marcos regulatórios sul-americanos de organização intrapartidária. Objetivamente, a partir do referencial teórico de base adotado, representará um padrão efetivo de institucionalização de democracia interna aquele que preencher basicamente duas condições: inicialmente, precisará implementar uma dimensão ampla de participação dos filiados nos processos de tomada de decisão intrapartidários (incluem-se nessa esfera as regras sobre extensão do sufrágio na escolha dos membros dos órgãos de direção partidária e dos candidatos a mandatos eletivos); num segundo plano, precisará garantir a existência de uma dimensão competitiva deliberativa, isto é que dê oportunidade de participação às diferentes correntes políticas dentro de um mesmo partido (nesse âmbito estão as regras que ampliam a competição para cargos da direção partidária e 
para cargos eletivos do sistema político). A identificação de regras que contemplem ambas esferas - quais sejam: participação e competição intrapartidárias - será o eixo metodológico norteador da delimitação dos padrões regulatórios dos partidos políticos sul-americanos.

Esclarecidas as escolhas teóricas e metodológicas do presente estudo, é importante indicar a forma como está construído. Na primeira parte, identificam-se os padrões de regulação de democracia intrapartidária nos países sul-americanos, com enfoque nas suas distinções. A segunda parte, por sua vez, consiste no cotejo de tais padrões regulatórios com o projeto constitucional liberal-conservador (GARGARELLA, 2014), com o fim de trazer à tona sugestões de reformas institucionais que apresentam o potencial de aprofundar a democracia na região.

\section{A democracia intrapartidária na América do Sul: identificando os padrões regulatórios}

Embora apresentem um fio condutor comum na sua formação histórico-política (qual seja, a exploração colonialista), os percursos traçados pelos estados latino-americanos na construção de suas estruturas institucionais variaram significativamente de região para região. $\mathrm{Na}$ presente seção, avaliaremos os padrões de regulação partidária (constitucional e infraconstitucional) dos países sul-americanos durante (e logo após) a redemocratização desses Estados a partir da década de 1980.

No texto constitucional argentino vigente - Constituição de 1853 com as alterações promovidas pela reforma de 1860, 1866, 1898, 1957 e 1994 - os partidos políticos são reconhecidos como "instituições fundamentais do sistema democrático" (artigo 38). As normas constitucionais, entretanto remetem à legislação ordinária a regulamentação do seu funcionamento. Especificamente no contexto argentino, é a lei n. 23.298 (Lei Orgânica dos Partidos Políticos), de 1985, que cumpre o papel de definir os padrões de funcionamento das associações partidárias.

Depreende-se da leitura da lei n. 23.298 que a competência para definir as regras para eleição das autoridades partidárias (diretorias) fora atribuída às próprias entidades partidárias em suas respectivas normas estatutárias, com aplicação subsidiária da lei orgânica dos partidos políticos (artigo 29). A definição dos nomes dos candidatos a cargos eletivos, contudo, mereceu 
maior atenção do legislador ordinário: instituiu-se o sistema de eleições primárias abertas, simultâneas e obrigatórias em todo o território nacional, para o mesmo dia e para todos os partidos políticos.

Por via de consequência, a definição dos critérios que habilitarão os cidadãos a se candidatarem aos cargos de direção partidária fica a cargo das normas estatutárias de cada partido político. Por outro lado, ao dispor que a escolha dos candidatos a cargos eletivos deverá ocorrer via eleições primárias abertas, todos os cidadãos regularmente registrados no padrão eleitoral (independentemente de serem filiados à organização partidária) são obrigados a participar das primárias.

Na história do constitucionalismo brasileiro, a Constituição Federal de 1988 é aquela que conferiu maior grau de autonomia aos partidos políticos. Ainda que a Emenda Constitucional n.97, de 2017, tenha proposto uma redefinição na dinâmica do funcionamento das entidades partidárias - com a inclusão de uma cláusula de desempenho, inclusive - a regulação do funcionamento e da organização dos partidos políticos está na lei ordinária n. 9.096 (Lei de Partidos Políticos), de 1995.

Em relação à eleição dos cargos de direção das entidades partidárias, a Constituição Federal brasileira assegura às próprias entidades partidárias a prerrogativa de definir procedimentos e critérios para candidaturas. Na prática, a alta autonomia conferia às entidades partidárias abre espaço para a institucionalização de diferentes formas de escolha das autoridades de cada partido. De igual modo, a definição da instância legítima a realizar tal escolha (todos os filiados? Uma comissão de delegados?) fica ao encargo das normas estatutárias do respectivo partido político.

Por outro lado, a Constituição Federal de 1988 silencia quanto à forma de definição dos candidatos aos cargos eletivos. Nenhum procedimento de eleições primárias foi estabelecido, diferentemente da experiência argentina. Em evidente reprodução da matriz constitucional, a Lei de Partidos Políticos brasileira reconhece que os partidos são livres para estabelecer em seus estatutos as suas estruturas internas, organização e funcionamento (artigo 14). Também as condições e a forma de escolha dos candidatos a cargos e funções eletivas são matérias deslocadas, pela Lei de Partidos Políticos, para o âmbito dos estatutos partidários (artigo 15, inciso VI).

O mais recente texto constitucional promulgado na região latino-americana, isto é, a Constituição boliviana de 2009 , enfatiza que a organização e o funcionamento dos partidos 
políticos deverão ser democráticos e, que, a eleição interna das autoridades seria regulada e fiscalizada pelo Órgão Eleitoral Plurinacional (artigo 210, itens I e II). A regulação mais detalhada sobre a constituição, o financiamento e a democracia interna das organizações políticas fora apresentada pela Lei n.1096, de 2018, conhecida como "Lei de Organizações Políticas”. Referida norma infraconstitucional conceitua como "democracia interna” o exercício democrático e orgânico em todo processo de tomada de decisão política na estrutura e vida orgânica das organizações políticas, bem como a conformação de seus dirigentes e a seleção de suas candidaturas em todos os níveis (artigo 3, letra “e”).

A Lei de Organizações Políticas prevê que os estatutos partidários devem estabelecer procedimentos democráticos de eleição dos seus dirigentes e de seus candidatos a cargos eletivos (artigo 17, letras “e” e “f”). Nesse mesmo sentido é a orientação de que os partidos políticos podem adotar para a eleição, designação ou nomeação de seus dirigentes, delegados e candidatos diferentes mecanismos inerentes à democracia representativa, democracia direta e participativa e democracia comunitária, em conformidade com seus interesses. Mais diretamente em relação à forma de seleção das autoridades partidárias, a Lei n.1096 define que os procedimentos democráticos e paritários para a tal eleição deve constar nos respectivos estatutos (artigo 26, item I).

Quanto à forma de escolha dos candidatos à cargos eletivos, a matriz normativa é muito semelhante, ainda que um pouco mais detalhada - na legislação mencionada. Além de impor que os estatutos estabeleçam procedimentos democráticos e paritários para escolha dos candidatos a cargos públicos (artigo 28, item I), a Lei de Organizações Políticas orienta que a definição dessas candidaturas esteja permeada pela maior participação possível de militantes (artigo 28, item II). Uma especificidade, entretanto, marca a forma de escolha dos candidatos aos cargos de Presidente e Vice Presidente da República: impôs-se um processo eleitoral primário, obrigatório e simultâneo (artigo 29). O binômio de cada partido político será escolhido pelos militantes que estiverem registrados no padrão eleitoral da respectiva entidade partidária - e os resultados da eleição primária serão vinculantes.

Enquanto base jurídico-política da transição chilena para a democracia no final do século XX, a Constituição Política de 1980 - atualmente vigente - impõe que os estatutos partidários deverão contemplar normas que assegurem uma efetiva democracia interna (artigo 19, inciso XV). Na esfera infraconstitucional, assumem importância na regulamentação de democracia intrapartidária no Chile a Lei n. 18.603, de 1987, denominada "Lei Orgânica 
Constitucional dos Partidos Políticos" e a Lei n. 20.640, de 2012, que estabelece um sistema de eleições primárias para candidatos a cargos eletivos.

Quanto à forma de eleição das autoridades partidárias, a Lei Orgânica Constitucional dos Partidos Políticos (Lei n.18.603) prescreve que cabe à própria agremiação partidária estabelecer a forma de eleição de suas autoridades (artigo 5, "E”). A norma infraconstitucional apenas traz diretrizes gerais referentes à eleição das autoridades partidárias tais como a imposição de que o mandato para tais cargos não pode seja superior a 4 anos, sendo permitida apenas uma recondução consecutiva para a mesma função (artigo 23). Em relação à extensão do sufrágio em eleições intrapartidárias, a norma ordinária define que se considerarão habilitados para votar aquelas pessoas que se encontrem inscritas no registro de afiliados do partido (artigo 23, "bis").

A Constituição Política chilena faculta aos partidos políticos a definição da forma dos candidatos a cargos eletivos serem selecionados. A normatização desse procedimento ficou a cargo da Lei n. 20.640, de 2012, que detalha as balizas das eleições primárias simultâneas e facultativas. Saliente-se que a decisão de escolher candidatos a cargos eletivos por meio de eleições primárias é exclusivamente da própria entidade partidária (artigo 9), que tem autonomia para limitar o objeto das eleições primárias para algum cargo eletivo específico (artigo 10), bem como para definir quem serão os habilitados a participar do processo eleitoral. Aqueles partidos políticos que se submeterem ao procedimento de eleições primárias regulado pela Lei n. 20.640, entretanto, estão vinculados aos resultados - de modo que somente poderão apresentar como candidato para o cargo eletivo em questão aquele que saíra vitorioso nas primárias (artigo 35).

A Constituição Política colombiana de 1991 impõe que os partidos e movimentos políticos se organizem democraticamente, facultando às organizações partidárias a realização de consultas populares ou internas para seus processos de tomada de decisão (artigo 107 da Constituição). Embora haja referência a um processo de eleição primária facultativo, o texto constitucional remete à legislação infraconstitucional a regulação do mesmo. Nesse sentido, assume relevância nessa matéria a Lei Estatutária n.1475, de 2011, que estabelece as regras de organização e de funcionamento dos partidos e movimentos políticos e dos processos eleitorais.

A Lei Estatutária 1475 especifica que dentre os conteúdos mínimos que devem estar regulados nos estatutos de cada partido político colombianos estão as formas de nomeação e destituição das autoridades diretivas e o procedimento de seleção de candidatos a cargos de 
eleição popular - que poderá ser feito por consultas populares ou não (artigo 4, itens 5 e 11). Especificamente quanto à forma de escolha dos candidatos à cargos eletivos, mencionado ato normativo salienta que além de serem facultativas, podem ser populares ou internas dependendo da extensão do direito de participação estabelecido no âmbito dos estatutos de cada partido político (artigo 5). Para aquelas agremiações partidárias que convocarem consultas (populares ou internas), entretanto, os resultados se impõem como obrigatórios (artigo 7).

Reproduzindo a linha de ampliação de autonomia das organizações partidárias presente na instância constitucional, a lei estatutária colombiana não regula a forma de eleição das autoridades internas, deixando tal assunto a cargo dos estatutos partidários. Verifica-se que a legislação infraconstitucional reitera a orientação constante na Constituição, detalhando o percurso procedimental das consultas internas facultativas, anunciadas no texto constitucional colombiano de 1991.

O texto constitucional equatoriano vigente desde 2008 não trata diretamente das questões envolvendo democracia intrapartidária, impondo de forma geral que os partidos políticos devem apresentar um programa de ação política em conformidade com o sistema democrático (artigo 115). Por outro lado, estabeleceu que o regime dos partidos políticos deveria ser regulado por lei orgânica (artigo 142). Assim, demonstra-se fundamental para os propósitos da presente abordagem a realização de uma investigação dos termos da Lei Orgânica n.2, de 2009, conhecida como "Lei Orgânica Eleitoral” ou "Código da Democracia”.

A terceira seção do "Código da Democracia" é intitulada de "Democracia interna das organizações políticas", e como matriz primordial destaca-se o direcionamento para que as estruturas e o funcionamento das entidades partidárias sejam democráticos e garantam a paridade de gênero (artigo 343). Enquanto peculiaridade, essa norma infraconstitucional estabelece que o processo de eleição das autoridades e a seleção de candidatos a cargos públicos de eleição popular ficarão sob a responsabilidade de um órgão eleitoral central (artigo 344), com atribuição para realizar todas as etapas dos processos eleitorais internos.

A lei faculta aos partidos políticos, todavia, a escolha da modalidade de eleição, por meio de seus respectivos estatutos. Dentre as possibilidades, nos termos na norma infraconstitucional em análise, estão (artigo 348): a) primárias abertas com voto universal; b) primárias fechadas; c) eleições representativas por meio de órgãos internos. Perceba-se que a terceira alternativa flexibiliza a participação direta, na medida em que viabiliza a institucionalização de eleições indiretas, por meio de órgãos internos representativos. Em 
última instância, a legislação infraconstitucional concedeu amplo poder às entidades partidárias para que estas fixem, em seus respectivos estatutos tanto a forma de seleção dos candidatos a cargos populares quanto o mecanismo de escolha das autoridades partidárias.

A Constituição paraguaia de 1992, em matéria de partidos políticos, restringiu-se a afirmar que a lei regularia a constituição e o funcionamento das entidades partidárias, com o fim de assegurar o caráter democrático das mesmas (artigo 125). Embora não haja uma lei específica sobre a regulamentação dos partidos políticos no Paraguai, esses temas estão contemplados na Lei n. 834, de 1996, conhecido como "Código Eleitoral” paraguaio. Essa norma infraconstitucional tem como princípio norteador a noção de que o funcionamento dos partidos políticos, assim como a sua organização, deverá ajustar-se a princípios democráticos (artigo 59)

Ao dispor sobre o conteúdo obrigatório dos estatutos partidários, o Código Eleitoral paraguaio estabelece que o estatuto de cada partido político deve conter regras de eleição das autoridades dos órgãos de direção nacional, departamental ou distrital - que deve ocorrer por meio de eleição direta entre os respectivos afiliados (artigo 32, letra "e"). As condições em que tais eleições ocorrerão, contudo, dependem de regulação estatutária de cada partido político. O Código Eleitoral confere alto grau de autonomia às instâncias deliberativas de cada partido ao reconhecer nelas a legitimidade para estabelecer quem pode ocupar os cargos de direção - ao prever que não poderão ser candidatos a cargos partidários quem, segundo os estatutos, não possa ser eleito (artigo 61).

Já em relação à seleção dos candidatos a cargo de eleição popular, o Código Eleitoral delega aos próprios partidos políticos a definição das normas aplicáveis (artigo 32, letra "p"), impondo que tal procedimento inclua eleição direta entre os afiliados. Entretanto, como não há referência à extensão do direito de participação dos afiliados nos processos de eleição dos candidatos à cargos eletivos, tal decisão fica a cargo de cada partido político que fixará tais balizas em seu respectivo estatuto (artigo 34).

A Constituição peruana de 1993 remete à legislação infraconstitucional a tarefa de regulamentar o funcionamento democrático das organizações partidárias (artigo 35). Nesse contexto, é importante investigar o tratamento dado à matéria pela Lei n. 28.094, de 2003, denominada de "Lei de Partidos Políticos".

A Lei de Partidos Políticos peruana confere às organizações partidárias tanto o poder de estabelecer a estrutura organizativa interna quanto o de definir os requisitos para tomada de 
decisões internas válidas (artigo 9, letras "b" e "c"). Embora haja previsão de que todos os membros terão direito de eleger e ser eleito para cargos do partido político, tal diretriz deve se ajustar às indicações do estatuto partidário - que é o instrumento competente para definir os contornos desses processos de eleição (artigos 19, 23 e 25). Tanto a eleição das autoridades quanto dos candidatos do partido político deve ser realizada por um órgão eleitoral central (artigo 20). Compete ao órgão máximo de cada partido político, com base nas regras estatutárias próprias, decidir sobre a modalidade de eleição dos candidatos à cargos eletivos dentre as três seguintes: eleições primárias universais, eleições primárias fechadas, eleições por meio de órgãos partidários - nos termos do estatuto (artigo 24).

Como se pode verificar, mesmo afirmando princípios básicos de democracia intrapartidária, a legislação infraconstitucional peruana transfere às entidades partidárias o poder de estabelecer os mecanismos de seleção das autoridades e de escolha dos candidatos a cargos eletivos. Em última instância, a autonomia partidária é privilegiada em grau bastante significativo.

Já nos termos da Constituição uruguaia de 1967 (com as modificações de 1989, 1994, 1996 e 2004), os partidos políticos deverão exercer efetivamente e democracia interna na eleição de suas autoridades (artigo 77, item 11, letra “a”), e eleger seus candidatos a Presidente da República (artigo 77, item 12) e intendentes municipais (artigo 271) mediante eleições internas reguladas por lei. Esta lei não foi editada até o presente momento, o que torna importante a compreensão de dispositivos constitucionais transitórios que regulam o tema. A lei infraconstitucional responsável pela regulação do funcionamento e da organização dos partidos políticos é a de número 18.485 , de 2009, mas esse instrumento normativo não enfrente diretamente a temática da democracia intrapartidária - razão pela qual as disposições constitucionais transitórias sobre o assunto seguem em pleno vigor.

A lei 18.485 se restringe a dispor que cada partido político decidirá sobre sua respectiva estrutura interna e sobre a forma de seu funcionamento, sem prejuízo das disposições de caráter geral estabelecidas pela Constituição e pela lei (artigo 3). No ato das disposições constitucionais transitórias, a Constituição Uruguaia prevê um procedimento de eleição primária universal e obrigatório para escolha dos candidatos à Presidência da República e ao parlamento (artigo 332, letra "w"). Os resultados desse processo de eleições primárias são vinculativos. 
Note-se que em relação à forma de eleição das autoridades partidárias há um amplo grau de autonomia dos partidos, que construirão essas regras em seus respectivos atos estatutários.

Por fim, destacamos que a Constituição venezuelana de 1999 não traz regulação específica sobre o funcionamento ou a organização das entidades político-partidárias. Na realidade venezuelana, é a Lei de Partidos Políticos, Reuniões Públicas e Manifestações, de 1965 com as reformas realizadas em 2010, que rege a matéria enfocada pelo presente trabalho, isto é, as normas de democracia interna dos partidos políticos.

Com relação à forma de seleção das autoridades partidárias, a mencionada lei refere que deve ser assegurado aos afiliados a participação direta ou representativa no governo do partido (artigo 5), o que permite amplo poder de decisão às organizações partidárias, na medida em que o mecanismo de seleção de suas autoridades deve ser definido pelas normas estatutárias. A lacuna na regulação do procedimento de escolha dos candidatos à cargos eletivos, no entanto, é ainda maior - na medida em que o assunto não é tratado pela norma infraconstitucional, o que resulta em uma enorme fortalecimento das elites partidárias, que se legitimam como peças fundamentais de institucionalização de processos de tomada de decisão extremamente centralizados ${ }^{2}$.

\section{O padrão regulatório dominante: o legado do constitucionalismo liberal-conservador}

Da análise realizada na seção anterior, é possível perceber que cada contexto institucional apresenta peculiaridades próprias da realidade histórico-cultural experimentada em cada região. Para além dessas particularidades, entretanto, é forçoso reconhecer a existência de um padrão de regulação da democracia intrapartidária nesses dois pontos investigados pela pesquisa, quais sejam, a forma de seleção das autoridades partidárias e o mecanismo de escolha das candidaturas a cargos eletivos. À exceção de Argentina e Uruguai, tem-se que as Constituições sul-americanas não se detiveram em estabelecer a forma de definição partidária dos candidatos a cargos eletivos. Nenhuma delas fixou regras democráticas de seleção das autoridades partidárias, a fim de evitar a centralização dos processos de tomada de decisão intrapartidária.

\footnotetext{
${ }^{2}$ A título de reflexão a esse respeito, note-se que o estatuto do Partido Socialista Unido da Venezuela (PSUV), que exerce o governo do país há mais de uma década, estabelece que os métodos de democracia intrapartidária (tal como e eleição direta, universal e secreta, por exemplo) para tomada de decisões internas serão determinados pelas instâncias de direção, de acordo com as condições políticas (artigo 5). ESTATUTOS DEL PARTIDO SOCIALISTA UNIDO DE VENEZUELA. Disponível em: http://www.psuv.org.ve/psuv/estatutos/. Acesso em 21 de janeiro de 2020.
} 
Esse padrão regulatório é reflexo de um desenho constitucional herdeiro de traços autoritários e elitistas decorrente da interação entre as correntes de pensamento que embasaram a emergência dos Estados nacionais na região latino-americana. De modo geral, os autores que têm como objeto a formação constitucional da América Latina convergem na delimitação de três correntes de pensamento: a conservadora, a liberal e a radical (GARGARELLA, 2014).

O "elitismo político" é a característica de destaque da corrente conservadora. A afirmação de que as massas populares precisavam ser guiadas por instrutores capazes de fazerem as melhores escolhas políticas está no eixo central do esboço institucional conservador. A lógica da exclusão dos vulneráveis é facilmente introduzida no discurso de proteção da soberania dos Estados recém-formados, de modo que o preconceito étnico, social e de gênero assume função importante na justificação da centralização do poder. Se, por despreparo, a maioria da população mostrava-se incapaz de participar dos processos de tomada de decisão, caberia então aos cidadãos "instruídos", "letrados" e "proprietários" conduzirem a administração dos interesses públicos, de maneira a consolidar a emancipação política recémconquistada.

A corrente liberal indicará a proteção da autonomia individual como pilar de sustentação do Estado, que só deixaria de ser expressão do arbítrio com a institucionalização de um sistema de "freios e contrapesos" suficientemente capaz de evitar abusos. O discurso liberal assume o compromisso com a "neutralidade" do Estado, na proposta de criar barreiras que tornem estanques as esferas privada e pública - de tal sorte que a segunda não tenha interferências na primeira. Além de problemática referente à delimitação do conteúdo desse conceito, noção de "neutralidade" estatal é traduzida pela linguagem liberal latino-americana de direitos - isto é, por meio dela afirma-se que a viabilização efetiva dos projetos individuais de cada cidadão só seria alcançado mediante a inclusão de direitos no texto constitucional. A reivindicação por inclusão de "listas de direitos" nas constituições - que resultará em posterior inchaço da parte dogmática - evidencia que a corrente liberal não se empenhou em propor um modelo original de exercício democrático do poder, limitando-se a afirmar a importância dos "freios e contrapesos", com a inclusão de controles endógenos - isto é, controles exercidos por instituições representativas do povo, e não pelo povo diretamente (controle exógeno).

Finalmente, importa delinear as premissas da corrente radical (ou republicana). O "radicalismo" tem como traço particular a afirmação do "autogoverno" como elemento imprescindível na organização do Estado, tendo em vista o rompimento com a estrutura 
colonial. A hipótese defendida pelos defensores do modelo radical é a de que qualquer pretensão de mudança política pressupõe uma necessária alteração no cenário social e econômico. A partir disso, ao levantar a bandeira da "revolução política" simultânea à "revolução social" - com alteração do modelo de desenvolvimento econômico então em implantação pelas elites criollas, o discurso republicano vincula o êxito de mudanças políticas à efetivação de transformações profundas no campo social. É justamente nesse aspecto que recairão as principais críticas radicais relativas ao modo de configuração dos Estados latinoamericanos recém-independentes: a suposta emancipação política não veio acompanhada de emancipação socioeconômica que respondesse à extrema desigualdade, já que "o governo cortesão da nobreza espanhola foi substituído pelos latifundiários, comerciantes e profissionais nativos" (MARIÁTEGUI, 2012, p.111).

Na primeira metade do século XIX as três correntes de pensamento constitucional apresentadas acima disputaram na seara política sem que uma delas assumisse o domínio efetivo na região latino-americana. A partir da identificação das premissas básicas presentes em cada uma das três visões político-econômicas, é possível afirmar que enquanto "conservadores" e "radicais" priorizaram a reestruturação da parte orgânica da Constituição (isto é, da organização das formas de exercício do poder), "liberais" se dedicaram à maximização das listas de direitos constitucionalmente assegurados (parte dogmática da Constituição). Este fato ajuda a explicar: $i$. o porquê da aliança entre os primeiros ser uma realidade somente em circunstâncias pontuais e esporádicas no contexto político da América Latina; e ii. o papel de destaque do modelo liberal na formação dos pactos políticos responsáveis pela conformação da estrutura social desenhada na região.

A movimentação e as reivindicações de caráter popular que repercutiram no continente europeu na década de 1840 tiveram reflexos importantes na América Latina. Com as revoluções democráticas de 1848 ocorridas na Europa, as classes dirigentes latino-americanas percebem a necessidade de bloquear a articulação dos setores sociais mais vulneráveis e o consequente fortalecimento de demandas populares. As promessas do movimento revolucionário europeu estavam diretamente relacionadas com as propostas republicanas da corrente radical latino-americana e, embora esta não estivesse em condições de se afirmar como hegemônica perante as demais, é inegável que as notícias chegadas do além-mar favoreceram a propagação dos ideais republicanos de igualdade e de autogoverno. 
É justamente com a intenção de evitar reformas radicais (profundas) na forma de exercício do poder que as correntes liberal e conservadora firmaram a aliança responsável pela delimitação das principais características do constitucionalismo latino-americano ao longo do século XIX. O pacto liberal-conservador resultou na elaboração de novas constituições relativamente estáveis que conformaram o "constitucionalismo de fusão".

Referidas constituições assumem a pretensão de definir um sistema de freios e contrapesos (proposta liberal) desequilibrado em favor do chefe do executivo (proposta conservadora) e não incluem compromissos sociais em favor de grupos marginalizados (proposta liberal e conservadora). No que diz respeito aos direitos assegurados por estes textos constitucionais, é de se destacar a preocupação maior em arrolar direitos individuais, com destaque ao direito (individual) de propriedade. Na prática, temos que na parte orgânica dessas constituições prevalece a sistemática conservadora enquanto na parte dogmática prepondera a lógica liberal. No geral esse quadro se mantem inalterado no decorrer do século XIX.

$\mathrm{Na}$ virada do século XIX para o XX, a mudança na realidade da estrutura socioeconômica da América Latina forçou uma reforma significativa nos textos constitucionais: era o "constitucionalismo social" ganhando espaço no contexto latino-americano. Nesse sentido, a organização das classes operárias - que avançam no enfrentamento das barreiras conservadoras do elitismo político e iniciam a caminhada em direção ao sufrágio universal força a incorporação de direitos sociais nos textos constitucionais. Fundamentalmente, as novas constituições elaboradas na primeira metade do século XX traduzem as reivindicações sociais em modificações na parte dogmática - o que resulta no gradual inchaço das listas de direitos, deixando-se a organização do poder de modo quase intocado, de tal forma que a concentração de poder permanece maculando, de uma forma geral, as estruturas políticas dos Estados latinoamericanos.

Ao retornar aos dados obtidos da análise do padrão de regulamentação da democracia intrapartidária nos países sul-americanos, é possível conectar o resultado obtido como reflexo da manutenção da lógica libera-conservadora - na medida em que valores democráticos são afirmados ao mesmo tempo em que se fecha o campo político para participação popular, isto é, define-se que os afiliados dos partidos políticos possuem direito de participação nos processos de seleção de autoridades partidárias e de escolha dos candidatos a cargos eletivos ao mesmo tempo em que se atribui às próprias entidades partidárias o delineamento desses mecanismos de 
seleção. Em última análise, entrega-se às organizações partidárias o poder de definir o grau de democratização de suas próprias estruturas.

A superação de entraves institucionais elitistas tais como os que se apresentam nos desenhos constitucionais sul-americanos em destaque exige o enfrentamento de uma questão teórica pouco discutida: apostar na ampliação das formas de participação popular nos processos de tomada de decisão política é esperar demais da democracia? Em efusivo aceno afirmativo, a reflexão proposta pelos cientistas políticos Steven Levitsky e Daniel Ziblatt é extremamente provocativa - pois traduz e atualiza, já na segunda década do século XXI, os argumentos do liberalismo-conservador. Partindo de referenciais liberais, os autores defendem que "a verdadeira proteção contra autoritários em potencial não foi o firme comprometimento da população com a democracia, mas, antes, os guardiões da democracia - os nossos partidos" (LEVITSKY; ZIBLATT, 2018, p.34-35). É a partir dessa premissa que se reconhece ter sido a implementação de eleições primárias presidenciais obrigatórias e vinculantes nos Estados Unidos o gatilho para o ingresso de outsiders (potencialmente autoritários) na política e, consequentemente, o início da morte da democracia (LEVITSKY; ZIBLATT, 2018).

A defesa da centralização das indicações dos nomes de candidatos no âmbito das elites partidárias chama atenção ao menos por duas razões. Primeiro porque a história parece não confirmar a tese segundo a qual o aumento do grau de democracia intrapartidária está relacionado com o aumento do êxito de líderes e personagens autoritários em pleitos eleitorais para a Presidência da República nos Estados Unidos. Não se pode ignorar que desde a implementação das primárias obrigatórias em 1972, os Estados Unidos teve sete Presidentes da República antes da ascensão de Donald Trump em 2016. Como explicar que essa alteração institucional (implementação das primárias obrigatórias) é a responsável pela atual crise da democracia norte-americana se nas últimas quatro décadas esse mecanismo manteve a higidez da democracia naquele país? Além disso, ao estudarmos a ascensão de regimes políticos que apresentam perspectivas autoritárias - de ontem ou de hoje - é possível averiguar que o impulso inicial dessas lideranças ocorreu por articulações das elites partidárias, e não por amplo apoio popular (vide os exemplos de Hitler, na Alemanha; de Mussolini, na Itália; ou de Bolsonaro, no Brasil).

Em segundo lugar, é de se destacar a visão marcadamente conservadora orientada a subestimar a capacidade construtiva do "povo", que é apresentado como uma entidade "infantil e manipulável" - e por essa razão, extremamente perigosa. No núcleo dessa concepção está a 
perspectiva moderna do consenso, segundo a qual o projeto de progresso somente se concretizaria com a pacificação social - isto é - com a pacificação dos conflitos sociais. Essa pretensão, embasada nas ideias de "indivíduo" e de "razão", fundamentou a perseguição daqueles sujeitos que expressavam comportamentos que não se ajustavam ao regime político em implementação a partir da ascensão do Estado Moderno. Nesse sentido, a modernidade apresenta um de seus efeitos mais perversos na construção da racionalidade burocrática: “a coisa pública tomou o caráter de exterioridade” (MAFFESOLI, 2005, p.29).

A desconstrução desse paradigma epistemológico demanda uma reformulação dos aportes teóricos que sustentam as estruturas institucionais democráticas. Nesse sentido, a teoria da democracia deliberativa tem muito a contribuir na medida em que atribui à prática da discussão política o papel de instrumento de acesso à verdade moral. A ampliação do debate público, por meio do incentivo à participação nas discussões políticas tende a obter um “consenso unânime ou seu substituto (o acordo majoritário), mas sem eliminar a possibilidade de rever esse resultado se a qualquer tempo puder ser demonstrado que ele não coincide com o resultado hipotético de um consenso ideal" (NINO, 2011, p.324). Assim, sustentando o valor epistemológico da prática democrática, é possível concluir que a superação dos dilemas enfrentados por comunidades políticas contemporâneas se dará com mais (e não menos) democracia.

\section{Considerações finais}

A presente pesquisa analisou o marco regulatório da democracia intrapartidária dos dez países sul-americanos, isto é, Argentina, Brasil, Bolívia, Chile, Colômbia, Equador, Paraguai, Peru, Uruguai e Venezuela. Como balizas para averiguação do grau de democracia interna institucionalizada nessa região adotamos a forma de seleção das autoridades partidárias e os procedimentos de escolha das candidaturas a cargos eletivos.

O enfrentamento dos dados obtidos revela a emergência de um padrão regulatório dominante, que está diretamente vinculado ao desenho institucional do constitucionalismo de fusão - hegemônico na região pelo menos a partir da segunda metade do século XIX. Na prática, verifica-se o reconhecimento - seja pelas Constituições, seja pelas legislação infraconstitucional - de valores democráticos a serem levados em consideração nos processos 
de tomada de decisão intrapartidária. Ocorre que o esse padrão regulatório desloca para as próprias entidades partidárias a atribuição de definir os procedimentos de escolha de seus dirigentes e de seus respectivos candidatos à disputa eleitoral. O poder centralizado nas cúpulas das organizações partidárias é um fator que auxilia na explicação do funcionamento de sistemas políticos elitistas que são refratários aos anseios da população - que permanece sem instrumentos efetivos de participação nos processos de tomada de decisão política.

A partir do marco teórico da democracia deliberativa, é possível repensar o papel da participação política na construção das decisões comunitárias, sobretudo ao se reposicionar a função do conflito no núcleo das comunidades. É o próprio conflito - e porque não dizer, a desordem - que funda o político, cuja essência é a ação e o diálogo (ARENDT, 2004). O fracasso do projeto da modernidade em afastar as emoções (e os conflitos que dela derivam) da seara política pode representar o norte para a articulação de uma teoria política antielitista e radicalmente democrática, que não se ressente em reconhecer o potencial criativo do povo.

\section{Referências bibliográficas}

ARENDT, Hannah. A condição humana. Rio de Janeiro: Forense Universitária, 2004.

ARGENTINA, Constituición Nacional de 1853 com la reforma de 1994. Disponível em: https://www.casarosada.gob.ar/nuestro-pais/constitucion-nacional Acesso em 20 de jan. de 2020.

Ley n. 23.298, de 1985. Disponível em: http://servicios.infoleg.gob.ar/infolegInternet/anexos/20000-24999/23893/texact.htm Acesso em 20 de jan. de 2020.

BRASIL, Constituição Federal de 1988. Disponível em: Acesso em: 20 de jan. de 2020.

$\begin{array}{cccccc}\text { Lei } & \text { n. } & \mathbf{9 . 0 9 6}, & \text { de } & 1995 . & \text { Disponível } \\ \text { http://www.planalto.gov.br/ccivil_03/LEIS/L9096.htm. Acesso em } & 20 \text { de jan. de } 2020 .\end{array}$

BOLÍVIA, Constituición Política del Estado Plurinacional de Bolívia, de 2009. Disponível em: https://bolivia.justia.com/nacionales/nueva-constitucion-politica-del-estado/.Acesso em 20 de jan. de 2020. 
Ley n. 1096, de 2018. Disponível em: https://bolivia.infoleyes.com/norma/6836/leyde-organizaciones-pol\%C3\%ADticas-1096. Acesso em 21 de jan. de 2020.

CHILE, Constituición Política de Chile, de 1980. Disponível em: https://www.leychile.cl/Navegar?idNorma=242302. Acesso em 21 de jan. de 2020.

Ley n. 18.603, de 1987. Disponível em: https://www.leychile.cl/Navegar?idNorma=29994..Acesso em 21 de jan. de 2020.

Ley n. 20.640, de 2012. Disponível em: https://www.leychile.cl/Navegar?idNorma=1046533\&r_c=6. Acesso em 22 de jan. de 2020.

COLÔMBIA, Constituición Política de Colombia, de 1991. Disponível em: http://es.presidencia.gov.co/normativa/normativa/Constitucion-Politica-Colombia-1991.pdf Acesso em 22 de jan. de 2020.

Ley estatutária 1.475, de 2011. Disponível em: https://wsr.registraduria.gov.co/IMG/pdf/ley_1475_2011.pdf. Acesso em 22 de jan. de 2020.

EQUADOR, Constituición del Ecudor, de 2008. Disponível em: https://www.oas.org/juridico/mla/sp/ecu/sp_ecu-int-text-const.pdf.Acesso em 22 de jan de 2020.

Ley Organica Electoral n.2, de 2009. Disponível em: https://www.oas.org/juridico/mla/sp/ecu/sp_ecu-int-text-const.pdf. Acesso em 22 de jan de 2020.

FREIDEMBERG, Flávia. La democratización de los partidos políticos en América Latina: entre la ilusión y el desencanto. In: SÁNCHEZ, José Thompson y Fernando. Fortalecimiento de los partidos políticos en América Latina: institucionalización, democracia y transparencia. San José de Costa Rica: IIDH, 2006.

GARGARELlA, Roberto. La sala de máquinas de la Constitución: dos siglos de constitucionalismo en América Latina (1810-2010). Buenos Aires: Katz, 2014.

KATZ, Richard; MAIR, Peter (ed.). How Party Organize: change and adaptation in party organization in Western democracies. London: Sage Publications Ltd., 1994.

LEVITSKY, Steven; ZIBLATT, Daniel. Como as democracias morrem. Rio de Janeiro: Zahar, 2018.

MAFFESOLI, Michel. A transfiguração do político: a tribalização do mundo. Porto Alegre: Sulina, 2005.

NINO, Carlos Santiago. Ética e direitos humanos. São Leopoldo: Editora UNISINOS, 2011. 
PARAGUAI, Constituición de la República de Paraguay, de 1992. Disponível em: http://jme.gov.py/transito/leyes/1992.html. Acesso em 14 de jan de 2020.

Ley n. 834, de 1996. Disponível em: https://www.oas.org/es/sap/deco/moe/Paraguay2013/docs/CODIGO_ELECTORAL.pdf. Acesso em 14 de jan. de 2020.

PERU, Constitución Política del Peru, de 1993. Disponível em: http://www4.congreso.gob.pe/ntley/Imagenes/Constitu/Cons1993.pdf. Acesso em 15 de jan. de 2020.

Ley n. 28.094, de 2003. Disponível em:

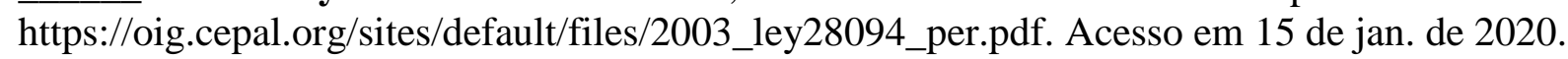

URUGUAI, Constitución de la República, de 1967 con las reformas de 1989, 1994 y 1996. Disponível em: https://parlamento.gub.uy/documentosyleyes/constitucion. Acesso em 15 de jan. de 2020.

$$
\text { Ley n. 18.485, de 2009. Disponível em: }
$$
https://legislativo.parlamento.gub.uy/temporales/leytemp6628592.htm. Acesso em 15 de jan. de 2020.

TEORELL, Jan. A deliberative defence of intra-party democracy. In: Party Politics, vol. 5, n.3, p.363-382, jul., 1999.

VENEZUELA, Constitución de la República Bolivariana de Venezuela, de 1999. Disponível em: https://www.oas.org/juridico/mla/sp/ven/sp_ven-int-const.html. Acesso em 16 de jan. de 2020.

. Ley de Partidos Políticos, Reuniones Publicas e Manifestaciones, de 1965. Disponível em: http://pdba.georgetown.edu/Parties/Venezuela/Leyes/LeyPartidos.pdf. Acesso em 16 de jan. de 2020.

ZOVATTO, Daniel. Regulación jurídica de los partidos políticos en América Latina. UNAM: Ciudad de Mexico, 2006. 